\title{
Gene Structure and Expression of the High-affinity Nitrate Transport System in Rice Roots
}

\author{
Chao Cai ${ }^{1,2,3}$, Jun-Yi Wang ${ }^{1,3}$, Yong-Guan Zhu ${ }^{2}$, Qi-Rong Shen ${ }^{4}$, Bin Li ${ }^{1}$, Yi-Ping Tong ${ }^{1 *}$ and \\ Zhen-Sheng $\mathrm{Li}^{1^{*}}$ \\ ( ${ }^{1}$ State Key Laboratory of Plant Cell and Chromosome Engineering, Institute of Genetics and Developmental Biology, the Chinese Academy of \\ Sciences, Beijing 100101, China; \\ ${ }^{2}$ Research Center for Eco-environmental Sciences, the Chinese Academy of Sciences, Beijing 100085, China; \\ ${ }^{3}$ Graduated University, the Chinese Academy of Sciences, Beijing 100049, China; \\ ${ }^{4}$ College of Resources and Environmental Sciences, Nanjing Agricultural University, Nanjing 210095, China)
}

\begin{abstract}
Rice has a preference for uptake of ammonium over nitrate and can use ammonium-N efficiently. Consequently, transporters mediating ammonium uptake have been extensively studied, but nitrate transporters have been largely ignored. Recently, some reports have shown that rice also has high capacity to acquire nitrate from growth medium, so understanding the nitrate transport system in rice roots is very important for improving $\mathbf{N}$ use efficiency in rice. The present study identified four putative NRT2 and two putative NAR2 genes that encode components of the high-affinity nitrate transport system (HATS) in the rice (Oryza sativa L. subsp. japonica cv. Nipponbare) genome. OsNRT2.1 and OsNRT2.2 share an identical coding region sequence, and their deduced proteins are closely related to those from mono-cotyledonous plants. The two NAR2 proteins are closely related to those from mono-cotyledonous plants as well. However, OsNRT2.3 and OsNRT2.4 are more closely related to Arabidopsis NRT2 proteins. Relative quantitative reverse transcription-polymerase chain reaction analysis showed that all of the six genes were rapidly upregulated and then downregulated in the roots of $\mathrm{N}$-starved rice plants after they were re-supplied with $0.2 \mathrm{mM}$ nitrate, but the response to nitrate differed among gene members. The results from phylogenetic tree, gene structure and expression analysis implied the divergent roles for the individual members of the rice NRT2 and NAR2 families. High-affinity nitrate influx rates associated with nitrate induction in rice roots were investigated and were found to be regulated by external $\mathrm{pH}$. Compared with the nitrate influx rates at $\mathrm{pH} 6.5$, alkaline $\mathrm{pH}(\mathrm{pH} \mathrm{8.0)}$ inhibited nitrate influx, and acidic $\mathrm{pH}$ (pH 5.0) enhanced the nitrate influx in $1 \mathrm{~h}$ nitrate induced roots, but did not significantly affect that in 4 to $8 \mathrm{~h}$ nitrate induced roots.
\end{abstract}

Key words: high-affinity nitrate transport system; nitrate influx; NRT2; NAR2; Oryza sativa.

Cai C, Wang JY, Zhu YG, Shen QR, Li B, Tong YP, Li ZS (2008). Gene structure and expression of the high-affinity nitrate transport system in rice roots. J. Integr. Plant Biol. 50(4), 443-451.

Available online at www.jipb.net

Rice is the staple food for more than half of the world's population. Nitrogen $(\mathrm{N})$ deficiency is the most common constraint to lowland rice production, and thus $\mathrm{N}$ fertilization is a key input in increasing rice production (Vlek and Byrnes 1986). However, $N$

Received 3 Nov. 2006 Accepted 8 Dec. 2006

Supported by the National Natural Science Foundation of China (30390080 and 30521001) and the Ministry of Science and Technology of China (2005CB120900 and 2004CB117200).

*Authors for correspondence.

Tel(Fax): +86 (0)10 6488 9381;

E-mail: <yptong@genetics.ac.cn> and <zsli@genetics.ac.cn>.

(C) 2008 Institute of Botany, the Chinese Academy of Sciences doi: 10.1111/j.1744-7909.2008.00642.x use efficiency (NUE) in lowland rice is often low. Upland crops frequently use $40-60 \%$ of the applied $\mathrm{N}$, while flooded rice plants typically use only $20-40 \%$ (Vlek and Byrnes 1986). The same is true for NUE in the lowland rice in China; loss of as much as $70 \%$ of the applied $\mathrm{N}$ fertilizers have been reported in high yielding rice fields in China (Zhu 2000). Therefore there is an urgent need to increase NUE for decreasing the costs of rice production, and the loss of $\mathrm{N}$, which can cause eutrophication of surface water bodies and contribute to the emission of greenhouse gases (Tilman 1999). Understanding the mechanisms of how the crop takes up $\mathrm{N}$ at a molecular level will help to improve NUE in rice.

Ammonium is the main form of plant-available $\mathrm{N}$ in flooded rice soils where the bulk of the soil is anaerobic (Sasakawa and Yamamoto 1978; Yu 1985). Rice has been reported by many 
to have a preference for ammonium uptake (Kronzucker et al. 1998, references therein), and performs well when ammonium is provided as the sole $\mathrm{N}$ source (Wang et al. 1993; Colmer and Bloom 1998; Kronzucker et al. 1998). Consequently, studies on molecular mechanisms of $\mathrm{N}$ uptake have mainly focused on ammonium transporters in rice (Kumar et al. 2003; Sonoda et al. 2003a, 2003b; Loque and von Wiren 2004). Many reports show that rice can also take up nitrate (Sasakawa and Yamamoto 1978; Kronzucker et al. 1999; Kronzucker et al. 2000), and nitrate can enhance ammonium uptake and metabolism of rice (Kronzucker et al. 1999). Additionally, a mixed $\mathrm{N}$ supply can increase biomass production and grain yield of rice ( $\mathrm{Ta}$ and Ohira 1981; Ta et al. 1981). However, the molecular mechanism of how rice takes up nitrate is not well understood. Presently, to our knowledge, only one nitrate transporter, OsNRT1 encoding a low-affinity nitrate transporter, has been functionally characterized (Lin et al. 2000). The existence and expression characteristics of high-affinity nitrate transporter genes in rice are still not clear.

Physiological and molecular studies revealed that there are two kinetically distinct nitrate uptake systems in plant roots: the low-affinity transport system (LATS) encoded by the NRT1 family, and the high-affinity transport system (HATS) encoded by the NRT2 family (Crawford and Glass 1998; Daniel-Vedele et al. 1998; Forde 2000; Galvan and Fernandez 2001; Glass et al. 2001; Williams and Miller 2001). The LATS generally has a larger capacity than does the HATS, and mediates nitrate uptake under high-nitrate environments (Siddiqi et al. 1990; Glass and Siddiqi 1995; Crawford and Glass 1998), while HATS appears to play a major role in nitrate uptake when nitrate concentrations in the soil are very low $(<250 \mu \mathrm{M})$ (for a review, see Crawford and Glass 1998). The first NRT2 gene nrtA (formerly known as crnA) was isolated from Aspergillus nidulans (Johnstone et al. 1990; Unkles et al. 1991), and was identified to be a functional nitrate/nitrite transporter when expressed in Xenopus oocytes (Zhou et al. 2000a). After the nrtA was isolated, a number of homologous genes were cloned from other eukaryotes, including Chlamydomonas reihardtii (Quesada et al. 1994), barley (Trueman et al. 1996; Vidmar et al. 2000a), wheat (Zhao et al. 2004), tobacco (Quesada et al. 1997), soybean (Amarasinghe et al. 1998), and Arabidopsis (Zhuo et al. 1999). In photosynthetic organisms (e.g. Chlamydomonas and barley), some NRT2-type transporters required a second protein, NAR2, to co-produce a functional HATS (Quesada et al. 1994; Zhou et al. 2000b; Tong et al. 2005). In Arabidopsis, disruption in a NAR2-like gene AtNRT3.1 caused a decrease in high-affinity nitrate influx (Okamoto et al. 2006). These cloned NRT2 and NAR2 genes helped us to identify the related family members in the rice genome. In the present study, four NRT2 and two NAR2 genes were isolated from rice. The phylogeny of these genes and their expression patterns in response to nitrate supply were analyzed. The effects of external $\mathrm{pH}$ on high-affinity nitrate influx rates were also investigated because $\mathrm{pH}$ may be an important factor in regulating the activity of the two components high affinity nitrate transport system (Tong et al. 2005).

\section{Results}

\section{Sequence analysis of rice NRT2 and NAR2 genes}

The protein sequences of barley NRT2.1 (accession no. AAC49531) and NAR2.3 (accession no. AAP31852) were used to identify related NRT2 and NAR2 genes in The Institute for Genomic Research (TIGR) rice genome database. Four putative NRT2 genes and two putative NAR2 genes were identified (Table 1). The six genes were distributed on three chromosomes, OsNRT2.3 and OsNRT2.4 on chromosome 1, OsNRT2.1, OsNRT2.2 and OsNAR2.1 on chromosome 2, and Os$N A R 2.2$ on chromosome 4. Alignment of the cDNA sequences of the four NRT2 genes showed that OsNRT2.1 and OsNRT2.2 have the same nucleotide sequences in their coding-regions (Table 1). OsNRT2.1 and OsNRT2.2 share $66 \%$ and $56 \%$ of nucleotide sequence identity with OsNRT2.3 and OsNRT2.4, respectively; the nucleotide sequence identity between OsNRT2.3 and OsNRT2.4 is $57 \%$ (Table 2). Further analysis of the genomic sequences of OsNRT2.1 and OsNRT2.2 revealed that the two genes are closely located in a "tail-to-tail" arrangement on chromosome 2 (Figure 1) and separated by another gene (LOC_Os02g02180). However, there are relative low values of the nucleotide sequence identity between the $5^{\prime}$ upstream regions and between the $3^{\prime}$ downstream regions of these two genes. The nucleotide sequence identity between the two OsNAR2 genes is $72 \%$. The gene structures differ among the four OsNRT2 genes, and between the two OsNAR2 genes. Of the four OsNRT2 genes, only OsNRT2.4 has intron (Figure 3). Although both of OsNAR2 genes have one intron, OsNAR2.1 has a much longer intron than OsNAR2.2.

The phylogenetic tree of NRT2 proteins was created after alignment on the entire sequences of NRT2 proteins including all of the four NRT2 proteins in rice, all the seven NRT2 proteins in Arabidopsis, and the NRT2 proteins in other plants, algae, fungi, and Escherichia coli. The phylogenetic tree of NRT2s clearly shows that there are two distinct clusters, one for dicotyledonous and the other for monocotyledonous plants. The NRT2 proteins from cereals are clustered together, within these the two rice sequences OsNRT2.1 and OsNRT2.2. OsNRT2.3 is more closely related to HvNRT2.5 and AtNRT2.5, and OsNRT2.4 is more closely related to AtNRT2.7. These five plant NRT2 proteins seem to be less related to other plant NRT2 proteins and might be more closely related to the NRT2 genes from lower eukaryotic organisms, or prokaryotic organisms (Figure 2A). The phylogenetic tree of NAR2 proteins also contains two distinct clusters, with the two OsNAR2 proteins in the monocotyledon cluster (Figure 2B). 
Table 1. Polymerase chain reaction (PCR) primers used in this study

\begin{tabular}{|c|c|c|c|}
\hline Gene & Locus $I D^{a}$ & Primer sequences for cDNA isolation & Product size (bp) \\
\hline \multirow[t]{2}{*}{ OsNRT2.1 } & LOC_Os01g50820 & Forward 5'-CTTCGACGTCAACCTCCAGA-3' & 664 \\
\hline & & Reverse 5'-CGATCCACAGAAGTAAATCAAACC-3' & \\
\hline \multirow[t]{2}{*}{ OsNRT2.2 } & LOC_Os02g02190 & Forward 5'-ATCCTTCGGCATGGCCAACAT-3' & 731 \\
\hline & & Reverse 5'-CTCCATGACGACATACTCTAG-3' & \\
\hline \multirow[t]{2}{*}{ OsNRT2.3 } & LOC_Os02g02170 & Forward 5'-ATCCTTCGGCATGGCCAACATC-3' & 911 \\
\hline & & Reverse 5'-GCTGGTCTCGGTCGCAGAATTGTT-3' & \\
\hline \multirow[t]{2}{*}{ OsNRT2.4 } & LOC_Os01g36720 & Forward 5'-GTCACCTACCTACTCCCGTG-3' & 798 \\
\hline & & Reverse 5'-ATCATCATCGTCATCAACATCGC-3' & \\
\hline \multirow[t]{2}{*}{ OsNAR2.1 } & LOC_Os02g38230 & Forward 5'-GCTGCTCTCTCGTTGGTGCT-3' & 518 \\
\hline & & Reverse 5'-ACCTTGAGGGAGGCGTGGAT-3' & \\
\hline \multirow[t]{2}{*}{ OsNAR2.2 } & LOC_Os04g40410 & Forward 5'-ACCTCTAGCAGAGAACGATCATGGCT-3' & 711 \\
\hline & & Reverse 5'-CTGTCGTACACAGTCACACATTACAA-3' & \\
\hline \multirow[t]{2}{*}{ OsACT } & LOC_Os03g50890 & Forward 5'-CCTCGTCTCGACCTTGCTGGG-3' & 666 \\
\hline & & Reverse 5'-GAGAACAAGCAGGAGGACGGC-3' & \\
\hline \multirow[t]{2}{*}{ Os18S rRNA } & LOC_Os09g00998 & Forward 5'-CTGCGA AAGCATTTGCCA-3' & 320 \\
\hline & & Reverse 5'-AGAAAGAGCTCTCAGTCTGT-3' & \\
\hline
\end{tabular}

aThe Institute for Genomic Research (TIGR) Rice Genome Annotation Locus ID.

Table 2. Identity/similarity of the NRT2 family

\begin{tabular}{lcccc}
\hline & \multicolumn{4}{c}{ Amino acid similarity } \\
\cline { 2 - 5 } Nucleotide identity & NRT2.1 & NRT2.2 & NRT2.3 & NRT2.4 \\
\hline NRT2.1 & - & 100 & 73 & 60 \\
NRT2.2 & 100 & - & 73 & 60 \\
NRT2.3 & 66 & 66 & - & 65 \\
NRT2.4 & 56 & 56 & 57 & - \\
\hline
\end{tabular}

\section{Expression patterns of NRT2 and NAR2 genes in} response to nitrate

The effects of two nitrate concentrations $(0.2$ and $2.0 \mathrm{mM})$ on the expression of OsNRT2 and OsNAR2 genes in rice roots were investigated using a semi-quantitative reverse transcriptionpolymerase chain reaction (RT-PCR) approach. When the plants deprived of $\mathrm{N}$ for $5 \mathrm{~d}$ were exposed to $0.2 \mathrm{mM}$ nitrate at $\mathrm{pH} 6.5$ for 0 to $12 \mathrm{~h}$ (Figure $3 \mathrm{~A}$ ), the mRNA levels of OsNRT2.1 and OsNAR2.1 increased slowly but significantly to their highest level at 2-4 h of treatment, and thereafter decreased steadily and slowly. The transcripts of OsNRT2.2 were rapidly upregulated and peaked at $1-2 \mathrm{~h}$, and then decreased rapidly. The transcripts of OsNRT2.4 and OsNAR2.2 increased within 0.5-1.0 h after nitrate feeding, remained at elevated levels until $4 \mathrm{~h}$ after nitrate feeding, and then declined sharply. By contrast, OsNRT2.3 had a transient inducible response to $0.2 \mathrm{mM}$ nitrate; its expression peaked within $15 \mathrm{~min}$ and then slowly decreased during the experiment period. The overall expression patterns of the six genes in roots treated with $2.0 \mathrm{mM}$ nitrate (Figure $3 \mathrm{~B}$ ) were similar to that treated with $0.2 \mathrm{mM}$ nitrate, but the transcripts of these genes (except OsNRT2.3) reached their highest
A

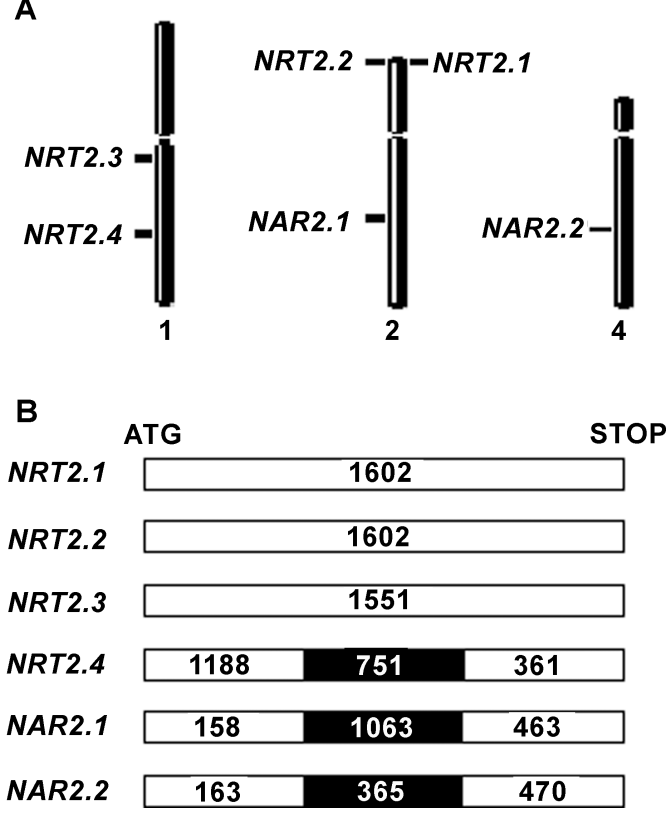

Figure 1. Locations and structures of NRT2 and NAR2 genes in rice genome.

(A) Distribution of NRT2 and NAR2 genes on chromosomes of rice. The genes shown to the right of the chromosome are transcribed in the + orientation (from the top down); the genes shown to the left of the chromosomes are transcribed in the - orientation (from the bottom up). (B) Exons and introns of the genes are indicated by white and black boxes, respectively. The size of exons and introns is given in bp inside the boxes. 

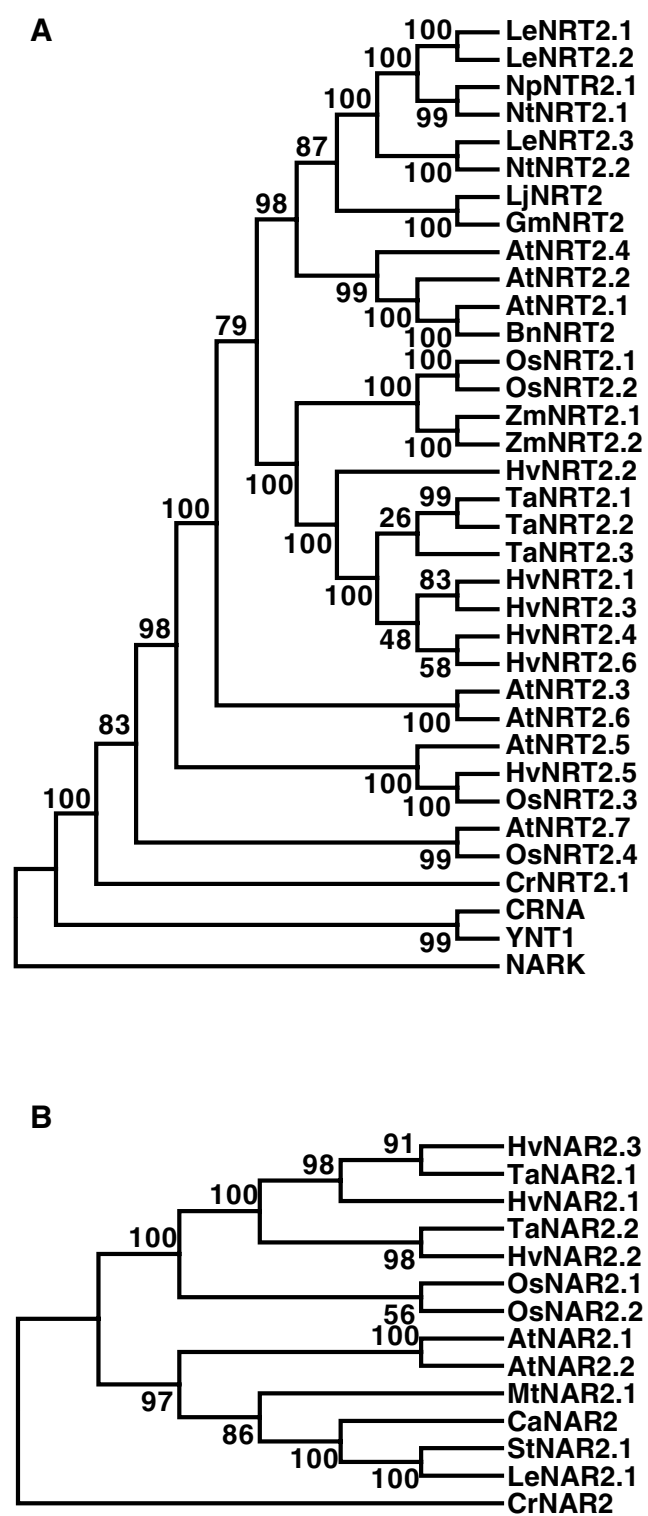

Figure 2. Phylogenetic trees of NRT2 (A) and NAR2 (B) families.

The entire protein sequences of NRT2 or NAR2 were aligned using ClustalW software, and then the alignments was used to create the unrooted, bootstrapped trees using MEGA version 3.0. Values indicate the number of times (in percent) that each branch topology was found during bootstrap analysis. The deduced protein sequences of the four OsNRT2 and two OsNAR2 genes from The Institute for Genomic Research (TIGR) Rice Genome Annotation Database were used in the present study (Table 1). Protein ID numbers of NRT2 are: barley (Hordeum vulgare) HvNRT2.1, AAC49531; HvNRT2.2, AAC49532; HvNRT2.3, AAD28363; HvNRT2.4, AAD28364; HvNRT2.5, ABG20828; HvNRT2.6, ABG20829; wheat (Triticum aestivum) TaNRT2.1, AAG01172; TaNRT2.2, AAK19519; TaNRT2.3, AAL11016; maize (Zea mays), ZmNRT2.1, AAN05088; ZmNRT2.2, level earlier in roots treated with $2.0 \mathrm{mM}$ nitrate than in the roots treated with $0.2 \mathrm{mM}$ nitrate.

\section{Effect of external pH on nitrate influx in nitrate induced roots}

The plants deprived of $\mathrm{N}$ for $5 \mathrm{~d}$ were first induced with $0.2 \mathrm{mM}$ nitrate at $\mathrm{pH} 6.5$ for $0,1,4$ and $8 \mathrm{~h}$, then the nitrate influx rates of these plants were measured in a solution containing $0.2 \mathrm{mM}$ ${ }^{15} \mathrm{~N}$-nitrate at $\mathrm{pH} 5.0,6.5$ and 8.0. The data in Figure $3 \mathrm{C}$ show that the nitrate influx rates increased with nitrate induction time from $1 \mathrm{~h}$ to $4 \mathrm{~h}$ and then did not increase any further at $8 \mathrm{~h}$. The effects of $\mathrm{pH}$ on nitrate influx rates were measured and the lowest values at all of the three time points were obtained at $\mathrm{pH}$ 8.0. The nitrate influx rate measured at $\mathrm{pH} 5.0$ was higher than that at $\mathrm{pH} 6.5$ at $1 \mathrm{~h}$, and was similar to that at $\mathrm{pH} 6.5$ at $4 \mathrm{~h}$ and $8 \mathrm{~h}$.

\section{Discussion}

The present study identified four NRT2 and two NAR2 genes in rice. It has been known that there are seven NRT2 and two NAR2 genes in Arabidopsis (Orsel et al. 2002), and six NRT2 and three NAR2 genes have been identified in barley (Figure 2). However, rice has more ammonium transporter (AMT) genes than Arabidopsis. According to the TIGR annotation database,

$\leftarrow$

AAT66252; Arabidopsis AtNRT2.1, NP_172288; AtNRT2.2, NP_172289; AtNRT2.3, NP_200886; AtNRT2.4, NP_200885; AtNRT2.5, NP_172754; AtNRT2.6, NP_190092; AtNRT2.7, NP_196961; tomato (Lycopersicon esculentum) LeNRT2.1, AAF00053; LeNRT2.2, AAF00054; LeNRT2.3, AAK72402; Nicotiana tabacum NtNRT2.1, CAD89798; NtNRT2.2, CAD89799; Brassica napus BnNRT2, CAC05338; Nicotiana plumbaginifolia NpNRT2.1, CAA69387; Lotus japonicus LjNRT2, CAC35729; soybean (Glycine max) GmNRT2, AAC09320; Chlamydomonas reinhardtii CrNRT2.1, CAA80925; Aspergillus nidulans CRNA, AAA62125; Hansenula polymorpha YNT1, CAA93631; and Escherichia coli NARK, CAA34126. Protein ID numbers of NAR2 are: barley HvNAR2.1, AAP31850; HvNAR2.2, AAP31851; HvNAR2.3, AAP31852; wheat TaNAR2.1, AAV35210; TaNAR2.2, AAV35211; Arabidopsis AtNAR2.1, CAC36292; AtNAR2.2, CAC36942; bell perper (Capsicum annuum), CaNAR2, AAM12786. The protein sequences of the NAR2 genes from tomato, potato, Medicago truncatula, and C. reinhardtii were deduced from the expressed sequence tag (EST) sequences using the National Center for Biotechnology Information (NCBI) open reading frame (ORF) finding tool. The accession numbers of the ESTs are: tomato LeNAR2.1, BF113833; pototo (Solanum tuberosum) StNAR2.1, BM109240; Medicago truncatula MtNAR2.1, BG584033; C. reinhardtii CrNAR2, BQ810103. 
A

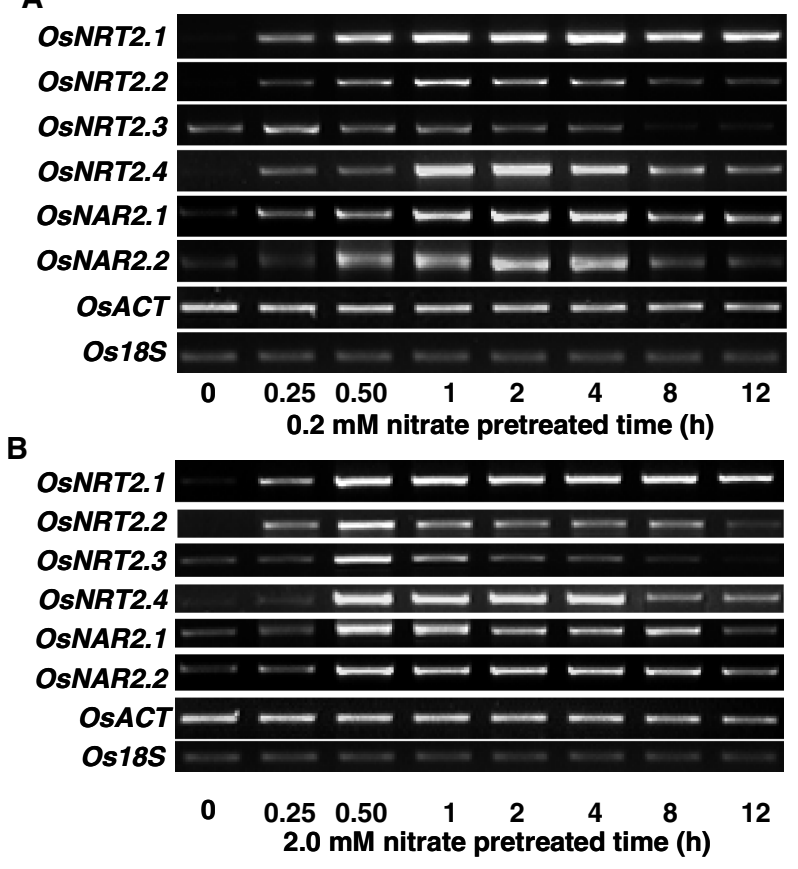

C

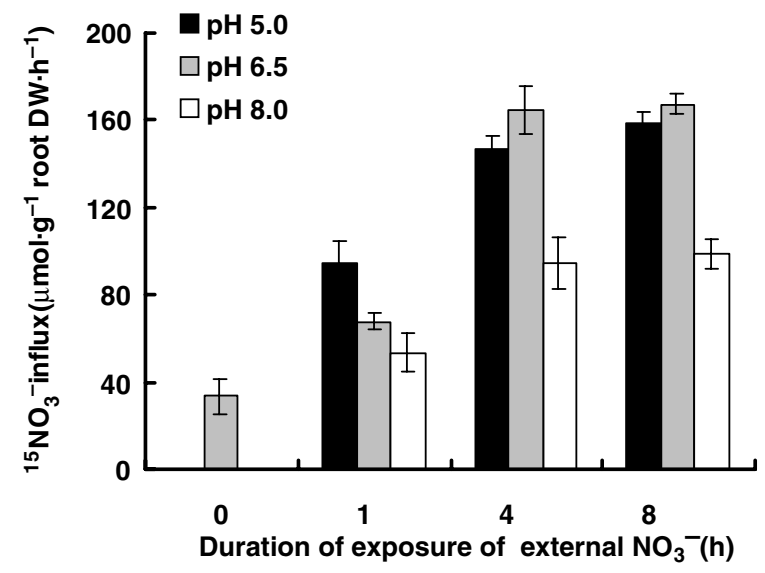

Figure 3. Expression patterns of the high-affinity nitrate transport system (HATS) genes and the effect of $\mathrm{pH}$ on nitrate influx in the roots pretreated with nitrate.

(A,B) Expression patterns of the HATS genes. Rice plants deprived of $\mathrm{N}$ for $5 \mathrm{~d}$ were resupplied with $0.2 \mathrm{mM}(\mathrm{A})$ and $2.0 \mathrm{mM}$ (B) nitrate at $\mathrm{pH} 6.5$ for the time as shown. Semi-quantitative reverse transcriptionpolymerase chain reaction (RT-PCR) was used to detect the mRNA levels in the roots. The constitutive gene actin and $18 S$ rRNA were used as a reference.

(C) The effect of $\mathrm{pH}$ on nitrate influx. Rice plants deprived of $\mathrm{N}$ for $5 \mathrm{~d}$ were resupplied with $0.2 \mathrm{mM}$ nitrate at $\mathrm{pH} 6.5$ for the time as indicated. The nitrate-induced plants were then used to measure nitrate influx in uptake solutions containing $0.2 \mathrm{mM}$ nitrate at $\mathrm{pH} 5.0,6.5$ and 8.0 as described in "Materials and Methods". The nitrate influx rates are given as the mean of four replicates and $S D$. there are 13 putative $A M T$ genes of which eight are expressed in rice, while there are six $A M T$ genes in Arabidopsis. The relatively small number of genes encoding HATS in rice relative to the number of putative ammonium transporters probably reflects the fact that rice grows in an ammonium richer environment. Rice has therefore been under evolutionary pressure to develop a more sophisticated ammonium rather than a nitrate uptake system and this is reflected in the number of genes available to transport each form of $\mathrm{N}$.

The six rice genes locate on three chromosomes (Figure 1). OsNRT2.1 and OsNRT2.2 are closely located in a "tail-to-tail" arrangement on the short arm of chromosome 2 and are separated by another gene. These two genes share identical coding sequences, but diverge in the $5^{\prime}$ upstream and $3^{\prime}$ downstream sequences, suggesting that a duplication event occurred. Interestingly, a similar arrangement has been observed for two Arabidopsis NRT2 genes, AtNRT2.1 and AtNRT2.2 (Orsel et al. 2002). Alignment of the entire protein sequences of rice NRT2 and other known NRT2 genes revealed that OsNRT2.1 and OsNRT2.2 belong to the monocotyledon cluster in the phylogenetic tree. Another two NRT2 genes (OsNRT2.3 and OsNRT2.4) locate on the long arm of chromosome 1. The protein sequences of these two NRT2 genes together with AtNRT2.5, AtNRT2.7 and HvNRT2.5 are more closely related to the NRT2 proteins from lower eukaryotic organisms or prokaryotic organisms than to other plant NRT2 proteins, implying that these NRT2 genes existed in higher plants before monocotyledon-dicotyledon split, or an ancient linkage before the divergence of monocotyledon from dicotyledon. Among the four rice NRT2 genes, only OsNRT2.4 has an intron. Therefore, most OsNRT2 genes have different structure from AtNRT2 genes that have one to three introns (Orsel et al. 2002). It is worth noting that OsNRT2.4 not only encodes a putative protein closely related to AtNRT2.7, but also has a similar gene structure to AtNRT2.7. Both genes have an intron near the stop codon (Figure 1, Orsel et al. 2002). The two rice NAR2 genes, OsNAR2.1 and OsNAR2.2, are located on chromosomes 2 and 4, respectively. Although both OsNAR2 genes have an intron near the start codon, OsNAR2.1 has a much longer intron than OsNAR2.2. The deduced polypeptides of OsNAR2.1 and OsNAR2.2 are more closely related to NAR2 proteins from monocotyledons than those from dicotyledons (Figure 2).

The investigation of the effects of nitrate treatment on individual members of the OsNRT2 family and OsNAR2 family revealed that these genes are differentially induced in root tissue treated with either low or high nitrate level (Figure $3 A, B$ ), indicating that these genes may have different roles in response to environmental nitrate. Although OsNRT2.2 has an identical coding sequence with OsNRT2.1 (Table 2), the mRNA levels of OsNRT2.2 increased to their peak earlier and then decreased more rapidly to a low level than that of OsNRT2.1 (Figure 3A). The different responses of OsNRT2.1 and OsNRT2.2 to nitrate could be attributed to their divergent $5^{\prime}$ upstream and/or $3^{\prime}$ 
downstream sequences. Among the six investigated genes, only OsNRT2.3 transiently responded to nitrate at the very beginning. The fact that high nitrate level more strongly induced OsNRT2.3 than low nitrate level implies that a high nitrate level may be required to induce this gene (Figure $3 A, B$ ). It was described earlier that some NRT2 type transporters from photosynthetic organisms required a second protein, NAR2, to co-produce a functional HATS (Quesada et al. 1994; Zhou et al 2000b; Tong et al. 2005; Orsel et al. 2006). As OsNRT2.3 expression responded to nitrate very differently to the two $N A R 2 s$, it therefore can be assumed that OsNRT2.3 does not require a second protein to function. Of the four rice NRT2 genes, the expression pattern of OsNRT2.1 best fitted with the change in pattern of the nitrate influx rates in response to nitrate induction (Figure 3), indicating that OsNRT2.1 might be a major member of inducible HATS. The data presented in Figure 3(A,B) clearly demonstrate that external nitrate levels did not affect the overall expression patterns of these six genes in roots in our experiment conditions. Similar results have also been reported for wheat and barley NRT2 genes (Vidmar et al. 2000a; Zhao et al. 2004).

High-affinity nitrate influx into rice root has been previously reported to be nitrate-inducible (Kronzucker et al. 2000) and this was also true in the present study (Figure $3 \mathrm{C}$ ). Using $0.2 \mathrm{mM}{ }^{15} \mathrm{~N}$-nitrate to measure the nitrate influx in the roots pretreated with $0.2 \mathrm{mM}$ nitrate at $\mathrm{pH} 6.5$ for the time as indicated in Figure $3 \mathrm{C}$, the nitrate influx increased 4.9 -fold from the onset to $4 \mathrm{~h}$ after exposure to nitrate. The nitrate influx at $8 \mathrm{~h}$ was similar to that at $4 \mathrm{~h}$, despite the fact that transcript abundances of all of the NRT2 and NAR2 genes decreased at $8 \mathrm{~h}$ (Figure 3A). This phenomenon (maintaining a high nitrate influx rate when NRT2 transcript abundance is low) has also been reported in barley (Vidmar et al. 2000b), and was possibly because other transport systems might contribute to the measured influx, or NRT2 or NAR2 genes were subjected to post-transcriptional regulation. A 4.9-fold induction of the nitrate influx measured at $\mathrm{pH} 6.5$ in present study was much lower than that previously reported. Using $0.1 \mathrm{mM}$ nitrate to measure the nitrate influx in the rice (cv. IR72) roots pretreated with $0.1 \mathrm{mM}$ nitrate at $\mathrm{pH} 6.5$, Kronzucker et al. (2000) detected a 27 -fold increase after $5 \mathrm{~h}$ of nitrate feeding. It has been reported in barley that the nitrate induction on high-affinity nitrate influx is genotype-dependent. The increase of influx associated with induction was less in Steptoe barley, which has higher constitutive high-affinity nitrate influx than in Klondike barley, which has lower constitutive highaffinity nitrate influx (King et al. 1993).

High-affinity nitrate influx into $0.2 \mathrm{mM}$ nitrate induced roots measured at $0.2 \mathrm{mM}{ }^{15} \mathrm{~N}$-nitrate and at various $\mathrm{pHs}$ revealed that the nitrate influx rates associated with nitrate induction were subjected to $\mathrm{pH}$ regulation (Figure $3 \mathrm{C}$ ). As reported previously in maize and barley (Glass et al. 1990; McClure et al. 1990), inhibition of alkaline $\mathrm{pH}$ on nitrate influx into nitrate induced rice roots was observed (Figure $3 \mathrm{C}$ ), reflecting the fact that trans-membrane nitrate transport is mediated by a proton-nitrate symport (Ullrich and Novacky 1981; Glass et al. 1992, Miller and Smith 1996). However, the effect of acidic $\mathrm{pH}$ on inducible nitrate influx depended on the time of the rice roots induced by nitrate. Compared with the influx rates measured at $\mathrm{pH} 6.5$, acidic $\mathrm{pH}(\mathrm{pH} 5.0)$ enhanced the nitrate influx into $1 \mathrm{~h}$ nitrate induced roots, but slightly reduced (though not significantly) the nitrate influx into roots induced by nitrate for $4 \mathrm{~h}$ and $8 \mathrm{~h}$ (Figure $3 \mathrm{C}$ ). It has been previously reported in barley that activities of different HATS systems are differentially regulated by external pH (Glass et al. 1990). Measurements of high-affinity ${ }^{13} \mathrm{~N}$-nitrate influx in $1 \mathrm{~d}$ nitrate-induced barley roots showed maximal influx at $\mathrm{pH} 6.0$ that was $19 \%$ lower at $\mathrm{pH} 4.5$ and $23 \%$ lower at $\mathrm{pH} 7.5$, but the highest influx in uninduced roots was observed at $\mathrm{pH} 4.5$ that was $16 \%$ lower at $\mathrm{pH} 6.0$ and $34 \%$ lower at $\mathrm{pH} 7.5$ (Glass et al. 1990). We also obtained similar results in barley with that observed by Glass et al. (1990) (Cai C. et al. unpubl. data, 2006). We measured high-affinity ${ }^{15} \mathrm{~N}$-nitrate influx in nitrate induced and uninduced barley roots at $\mathrm{pH}$ 5.0, 6.5 and 8.0 under approximately the same conditions used in the present study. The measured influx rates in uninduced roots at $\mathrm{pH} 5.0,6.5$ and 8.0 were $28.2,22.6$ and $14.4 \mu \mathrm{mol} \cdot \mathrm{g}^{-1} \mathrm{Dw} \cdot \mathrm{h}^{-1}$, respectively; while the influx rates in 4-12 h nitrate induced roots were the highest at $\mathrm{pH} 6.5$ that were $20-29 \%$ lower at $\mathrm{pH} 5.0$ and $31-44 \%$ lower at $\mathrm{pH}$ 8.0. The above data from the present study and the published reports demonstrated that alkaline $\mathrm{pH}$ inhibits highaffinity nitrate influx in the roots of both rice and barley, and acidic $\mathrm{pH}$ inhibits high-affinity nitrate influx in nitrate-induced roots of barley, but not rice.

In summary, the present study identified four NRT2 and two $N A R 2$ genes in rice roots. The protein sequence divergences within the OsNRT2 family and within the OsNAR2 family indicate their functional divergences. All six genes are nitrate-inducible, but they differentially respond to nitrate, indicating their different roles in adaptation to environmental conditions. Although the present study provided structure and expression data of the rice HATS components to understand the rice HATS, more detailed research is needed to analyze the kinetic characteristics of each NRT2 member, and the temporal and spatial expression pattern of these six genes. Acidic $\mathrm{pH}$, which has been shown to inhibit inducible high-affinity nitrate influx in barley, does not inhibit that in rice. Future research to understand this difference will help us to engineer crops with high activity of HATS under broad external $\mathrm{pH}$ values.

\section{Materials and Methods}

\section{Preparation of plant materials}

Rice (Oryza sativa L. subsp. japonica cv. Nipponbare) seeds were surface sterilized in $10 \% \mathrm{H}_{2} \mathrm{O}_{2}$ for $10 \mathrm{~min}$, then rinsed thoroughly with deionized water. The sterilized seeds were 
germinated and grown in moisture perlite (with nutrient solution, see below) for $25 \mathrm{~d}$. Uniform seedlings were then transferred to a tank containing $45 \mathrm{~L}$ of nutrient solution. The nutrient solution was the modified Yoshida nutrient solution (Yoshida 1976) in which $2 \mathrm{mM} \mathrm{KNO}_{3}$ was used as the sole $\mathrm{N}$ source. The solution $\mathrm{pH}$ was buffered at $6.5 \pm 0.2$ by adding $2 \mathrm{mM}$ 2-(N-morpholino)ethanesulfonic acid (MES). The solution was refreshed every $2 \mathrm{~d}$. After growing in the hydroponic tanks for $10 \mathrm{~d}$, the plants were then removed to $\mathrm{N}$-free solution $(\mathrm{pH} 6.5)$ for $5 \mathrm{~d}$ prior to analysis of gene expressions and nitrate influx rate measurements. The $\mathrm{N}$-free nutrient solution contained $2 \mathrm{mM}$ $\mathrm{KCl}$ instead of $2 \mathrm{mM} \mathrm{KNO}_{3}$, and was refreshed every day. In the present study, all plants were grown in a growth chamber with a $16: 8 \mathrm{~h}$ light: dark cycle at $28: 20 \pm 2{ }^{\circ} \mathrm{C}$. The relative humidity was kept at $65-70 \%$, and the light intensity at the plant level was $400 \mu \mathrm{mol} \cdot \mathrm{m}^{-2} \cdot \mathrm{s}^{-1}$.

\section{Expression patterns of NRT2 and NAR2 genes in response to nitrate}

To analyze the expression patterns of NRT2 and NAR2 genes in response to nitrate, the plants deprived of $\mathrm{N}$ for $5 \mathrm{~d}$ were exposed to the nutrient solution containing $0.2 \mathrm{mM}$ or $2.0 \mathrm{mM}$ $\mathrm{KNO}_{3}(\mathrm{pH} 6.5)$ for the time as indicated in Figure $3(\mathrm{~A}, \mathrm{~B}) . \mathrm{KCl}$, if needed, was used to keep potassium concentration at $2.0 \mathrm{mM}$ as that used in the $\mathrm{N}$-free nutrient solution. Three replicates for each time point were used. The treated root tissues were collected and stored at $-80^{\circ} \mathrm{C}$ for future analysis.

\section{Measurement of nitrate influx}

Intact seedlings were used to measure nitrate influx rates according to the methods described previously (Siddiqi et al. 1989; Kronzucker et al. 1998). The plants deprived of $\mathrm{N}$ for $5 \mathrm{~d}$ were induced with the nutrient solution containing $0.2 \mathrm{mM}$ $\mathrm{KNO}_{3}$ at $\mathrm{pH} 6.5$ for $0,1,4$, and $8 \mathrm{~h}$. Then eight nitrate-induced plants with similar size were transferred to a pot containing $0.5 \mathrm{~L}$ of $0.2 \mathrm{mM} \mathrm{NO}_{3}{ }^{-}$at $\mathrm{pH} 5.0,6.5$ or 8.0 for $5 \mathrm{~min}$. After this pretreatment, the eight plants were transferred to a pot containing $0.5 \mathrm{~L}$ of $0.2 \mathrm{mM}{ }^{15} \mathrm{~N}-\mathrm{KNO}_{3}\left(98 \%\right.$ atom ${ }^{15} \mathrm{~N}-\mathrm{KNO}_{3}$, Fluka-Aldrich Company, Miamisburg, $\mathrm{OH}, \mathrm{USA}$ ) at pH 5.0, 6.5 or 8.0 for $10 \mathrm{~min}$. Thereafter, the plants were transferred to an unlabeled nutrient solution contain $0.2 \mathrm{mM} \mathrm{KNO}_{3}$ for $3 \mathrm{~min}$ to remove tracer from the cell wall (Kronzucker et al. 1996). Four replicates for each treatment were used. The root and shoot samples were harvested separately, and dried at $70^{\circ} \mathrm{C}$. The plant samples were ground carefully using a pestle and mortar after their dry weights were recorded. The ${ }^{15} \mathrm{~N} /{ }^{14} \mathrm{~N}$ ratio in the ground samples was measured using an isotope ratio mass spectrometer with elemental analyzer (Thermo Finnigan MAT DELTA ${ }^{\text {plus }}$ XP, Bremen, Germany). Nitrate influx rate was calculated according to micromoles of ${ }^{15} \mathrm{~N}$ accumulated in the plant (root plus shoot) per gram root dry weight per $\mathrm{h}$.

\section{RNA isolation and relative quantitative RT-PCR}

The protein sequences of barley NRT2.1 and NAR2.3 were used to identify related NRT2 and NAR2 genes in TIGR rice genome database, four putative NRT2 genes and two putative NAR2 genes were identified (Table 1). Relative quantitative RT-PCR was used to determine the expression of individual NRT2 and $N A R 2$ genes in rice roots. Total RNAs were isolated from roots using TRIzol total RNA isolation reagent (Invitrogen, Carlsbad, CA, USA) according to the manufacturer's instructions. First strand cDNA synthesis was carried out on $2 \mu \mathrm{g}$ total RNA as a template using M-MLV RT (Invitrogen, Carlsbad, CA, USA) and 5 pmol of oligodT (Promega, Madison, WI, USA), following the manufacturer's recommended protocol. PCR reactions were carried out using one-twentieth of the first strand cDNA as templates. Taq DNA polymerase and dNTPs used in all reactions were provided by MBI Fermentas (Foster City, CA, USA). Gene specific primers were designed according to the predicated mRNA sequences or related EST sequences (Table 1). Os18SrRNA and OsActin (Table 1) were used as an internal control in the RT-PCR. PCR cycling conditions were as follows: an initial denaturation step at $95^{\circ} \mathrm{C}$ for $4 \mathrm{~min}$, amplification 25-41 cycles $\left(95^{\circ} \mathrm{C}\right.$ for $30 \mathrm{~s}, 58^{\circ} \mathrm{C}$ for $30 \mathrm{~s}$, and $72^{\circ} \mathrm{C}$ for $50 \mathrm{~s}$ ), and a final elongation step at $72^{\circ} \mathrm{C}$ for $10 \mathrm{~min}$. The PCR products were visualized on ethidium bromide stained $1.0 \%$ agarose gel, and confirmed by sequencing.

\section{Acknowledgements}

The authors would like to thank Dr. Anthony J. Miller for critically reading the manuscript.

\section{References}

Amarasinghe BHRR, Debruxelles GL, Braddon M, Onyeocha I, Forde BG, Udvardi MK (1998). Regulation of GMNRT2 expression and nitrate transport activity in soybean (Glycine max). Planta 206, 44-52.

Colmer TD, Bloom AJ (1998). A comparison of net $\mathrm{NH}_{4}{ }^{+}$and $\mathrm{NO}_{3}{ }^{-}$fluxes along roots of rice and maize. Plant. Cell Environ. 21, 240-246.

Crawford NM, Glass ADM (1998). Molecular and physiological aspects of nitrate uptake in plants. Trends Plant Sci. 3, 389-395.

Daniel-Vedele F, Filleur S, Caboche M (1998). Nitrate transport: a key step in nitrate assimilation. Curr. Opin. Plant Biol. 3, 235-239.

Forde BG (2000). Nitrate transporters in plants: structure, function and regulation. Biochim. Biophy. Acta 1465, 219-235.

Galvan A, Fernandez E (2001). Eukaryotic nitrate and nitrite transporters. Cell Mol. Life Sci. 58, 225-233.

Glass A, Brito D, Kaiser B, Kronzucker HJ, Kumar A, Okamoto M et al. (2001). Nitrogen transport in plants, with an emphasis on the regulation of fluxes to match plant demand. J. Plant Nutr. Soil Sci. 164, 199-207. 
Glass ADM, Shaff JE, Kochian LV (1992). Studies of the uptake of nitrate in barley. IV. Electrophysiology. Plant Physiol. 99, 456-463.

Glass ADM, Siddiqi MY (1995). Nitrogen absorption by plant roots. In: Srivastava HS, Singh RP, eds. Nitrogen Nutrition in Higher Plants. Associated Publishers, New Delhi. pp. 21-56.

Glass ADM, Siddiqi MY, Ruth TJ, Rufty TW (1990). Studies of the uptake of nitrate in barley: II. Energetics. Plant Physiol. 93, 15851589.

Johnstone IL, McCabe PC, Greaves P, Gurr SJ, Cole GE, Brow MAD et al. (1990). Isolation and characterization of the crnA-niiA-niaD gene cluster for nitrate assimilation in Aspergillus nidulans. Gene 90, 181-192.

King BJ, Siddiqi MY, Ruth TJ, Warner RL, Glass ADM (1993). Feedback regulation of nitrate influx in barley roots by nitrate, nitrite, and ammonium. Plant Physiol. 102, 1279-1286.

Kronzucker HJ, Glass ADM, Siddiqi MY, Kirk GJD (2000). Comparative kinetic analysis of ammonium and nitrate acquisition by tropical lowland rice: implications for rice cultivation and yield potential. New Phytol. 145, 471-476.

Kronzucker HJ, Kirk GJD, Siddiqi MY, Glass ADM (1998). Effects of hypoxia on ${ }^{13} \mathrm{NH}_{4}{ }^{+}$influxes in rice roots: kinetics and compartmental analysis. Plant Physiol. 116, 581-587.

Kronzucker HJ, Siddiqi MY, Glass ADM (1996). Kinetics of $\mathrm{NH}_{4}{ }^{+}$influx in spruce. Plant Physiol. 110, 773-779.

Kronzucker HJ, Siddiqi MY, Glass ADM, Kirk GJD (1999). Nitrateammonium synergism in rice: a subcellular flux analysis. Plant Physiol. 119, 1041-1046.

Kumar A, Silim SN, Okamoto M, Siddiqi MY, Glass ADM (2003). Differential expression of three members of the AMT1 gene family encoding high-affinity $\mathrm{NH}_{4}{ }^{+}$transporters in Oryza sativa sub species indica. Plant Cell Environ. 26, 907-914.

Lin CM, Koh S, Stacey G, Yu SM, Lin TY, Tsay YF (2000). Cloning and functional characterization of a constitutively expressed nitrate transporter gene, OsNRT1, from rice. Plant Physiol. 122, 379388.

Loque D, von Wiren N (2004). Regulatory levels for the transport of ammonium in plant roots. J. Exp. Bot. 55, 1293-1305.

McClure PR, Kochian LV, Spanswick RM, Shaff JE (1990). Evidence for cotransport of nitrate and proton in maize roots. I. Effects of nitrate on the membrane potential. Plant Physiol. 93, 281-289.

Miller AJ, Smith SJ (1996). Nitrate transport and compartmentation in cereal root cells. J. Exp. Bot. 47, 843-854.

Okamoto M, Kumar A, Li W, Wang Y, Siddiqi MY, Crawford NM et al. (2006). High-affinity nitrate transport in roots of Arabidopsis depends on expression of the NAR2-like gene AtNRT3.1. Plant Physiol. 140, 1036-1046.

Orsel M, Chopin F, Leleu O, Smith SJ, Krapp A, Daniel-Vedele F et al. (2006). Characterisation of a two component high affinity nitrate uptake system in Arabidopsis: physiology and protein-protein interaction. Plant Physiol. 142, 1304-1317.

Orsel M, Krapp A, Daniel-Vedele F (2002). Analysis of the NRT2 nitrate transporter family in Arabidopsis. Structure and gene expression. Plant Physiol. 129, 886-896.
Quesada A, Galvan A, Fernandez E (1994). Identificacion of nitrate transporters in Chlamydomonas reinhardtii. Plant. J. 5, 407-419.

Quesada A, Krapp A, Trueman LJ, Daniel-Vedele F, Fernandez E, Forde BG et al. (1997). PCR-identification of a Nicotiana plumbaginifolia cDNA homologous to the high-affinity nitrate transporters of the crnA family. Plant Mol. Biol. 34, 265-274.

Sasakawa H, Yamamoto Y (1978). Comparison of the uptake of nitrate and ammonium by rice seedlings-influences of light, temperature, oxygen concentration, exogenous sucrose, arid metabolic inhibitors. Plant Physiol. 62, 665-669.

Siddiqi MY, Glass ADM, Ruth TJ, Fernando M (1989). Studies of the regulation of nitrate influx by barley seedlings using ${ }^{13} \mathrm{NO}_{3}{ }^{-}$. Plant Physiol. 90, 806-813.

Siddiqi MY, Glass ADM, Ruth TJ, Rufty TW (1990). Studies of the uptake of nitrate in barley. I: Kinetics of ${ }^{13} \mathrm{NO}_{3}{ }^{-}$influx. Plant Physiol. 93, 1426-1432.

Sonoda Y, Ikeda A, Saiki S, von Wiren N, Yamaya T, Yamaguchi J (2003a). Distinct expression and function of three ammonium transporter genes (OsAMT1;1-1;3) in rice. Plant Cell Physiol. 44, 726-734.

Sonoda Y, Ikeda A, Saiki S, Yamaya T, Yamaguchi J (2003b). Feedback regulation of the ammonium transporter gene family AMT1 by glutamine in rice. Plant Cell Physiol. 44, 1396-1402.

Ta TC, Ohira K (1981). Effects of various environmental and medium conditions on the response of indica and japonica rice plants to ammonium and nitrate nitrogen. Soil Sci. Plant Nutr. 27, 347355.

Ta TC, Tsutsumi M, Kurihara K (1981). Comparative study on the response of Indica and Japonica rice plants to ammonium and nitrate nitrogen. Soil Sci. Plant Nutr. 27, 83-92.

Tilman D (1999). Global environmental impacts of agricultural expansion: The need for sustainable and efficient practices. Proc. Natl. Acad. Sci. USA 96, 5995-6000.

Tong YP, Zhou JJ, Li ZS, Miller AJ (2005). A two-component highaffinity nitrate uptake system in barley. Plant J. 41, 442-450.

Trueman LJ, Richardson A, Forde BG (1996). Molecular cloning of higher plant homologues of the high-affinity nitrate transporters of Chlamydomonas reinhardtii and Aspergillus nidulans. Gene 175, 223-231.

Ullrich WR, Novacky A (1981). Nitrate-dependent membrane potential changes and their induction in Lemna gibba. Plant Sci. Lett. 22, 211-217.

Unkles SF, Hawker KL, Grieve C, Campbell El, Montague P, Kinghorn JR (1991). crnA encodes a nitrate transporter in Aspergillus nidulans. Proc. Natl. Acad. Sci. USA 88, 204-208.

Vidmar JJ, Zhuo D, Siddiqi MY, Glass ADM (2000a). Isolation and characterization of HvNRT2.3 and HvNRT2.4, cDNAs encoding highaffinity nitrate transporters from roots of barley. Plant Physiol. 122, 783-792.

Vidmar JJ, Zhuo D, Siddiqi MY, Schoerring JK, Touraine B, Glass ADM (2000b). Regulation of high affinity nitrate transporter genes and high affinity nitrate influx by nitrogen pools in plant roots. Plant Physiol. 123, 307-318. 
Vlek PLG, Byrnes BH (1986). The efficacy and loss of fertilizer N in lowland rice. Fert. Res. 9, 131-147.

Wang MY, Siddiqi MY, Ruth TJ, Glass ADM (1993). Ammonium uptake by rice roots. I. Fluxes and subcellular distribution of ${ }^{13} \mathrm{NH}_{4}{ }^{+}$. Plant Physiol. 103, 1249-1258.

Williams LE, Miller AJ (2001). Transporters responsible for the uptake and partitioning of nitrogenous solutes. Annu. Rev. Plant Physiol. Plant Mol. Biol. 52, 659-688.

Yoshida S (1976). Routine procedure for growing rice plants in culture solution. In: Yoshida S, Forno DA, Cook JH, Gomez KA, eds. Laboratory Manual for Physiological Studies of Rice. I.R.R.I. Press, Manila. pp. 61-66.

Yu TR (1985). Soil and plants. In: Yu TR, ed. Physical Chemistry of Paddy Soils. Science Press, Beijing. pp. 197-217.

Zhao XQ, Li YJ, Liu JZ, Li B, Liu QY, Tong YP et al. (2004).
Isolation and expression analysis of a high-affinity nitrate transporter TaNRT2.3 from roots of wheat. Acta Bot. Sin. 46, 347354.

Zhou JJ, Fernandez E, Galvan A, Miller AJ (2000b). A high affinity nitrate transport system from Chlamydomonas requires two gene products. FEBS Lett. 466, 225-227.

Zhou JJ, Trueman LJ, Boorer KJ, Theodoulou FL, Forde BG, Miller AJ (2000a). A high affinity fungal nitrate carrier with two transport mechanisms. J. Biol. Chem. 275, 39894-39899.

Zhu Z (2000). Loss of fertilizer $N$ from plants-soil system and the strategies and techniques for its reduction (in Chinese with an English abstract). Soil Environ. Sci. 9, 1-6.

Zhuo D, Okamoto M, Vidmar JJ, Glass ADM (1999). Regulation of a putative high-affinity nitrate transporter (Nrt2;1At) in roots of Arabidopsis thaliana. Plant J. 17, 563-568.

(Handling editor: Jin-Zhong Cui) 